\title{
DIVERSITY OF MAMMAL FAUNA FROM THE AREA CRICOVA-GOIAN OF ICHEL RIVER BASIN, REPUBLIC OF MOLDOVA
}

\author{
Alina Larion', Tatiana Cîrlig², Victoria Nistreanu', Vladislav Caldari', \\ Natalia Dibolscaia ${ }^{1}$, Victoria Burlacu ${ }^{1}$ \\ ${ }^{1}$ Institute of Zoology, Chișinău, Republic of Moldova, e-mail: alina.larion@zoology.md \\ ${ }^{2}$ State University of Tiraspol, Chisinau, Republic of Moldova
}

\begin{abstract}
The studies were performed in 2017- 2021 in various types of ecosystems from the area Cricova-Goian of Ichel river basin. 45 species of mammals were registered: one hedgehog species, 5 species of Soricomorpha, 12 bat species, 18 rodent species, one hare species, 6 carnivorous species and 2 artiodactyl species. The multiannual dynamics of bat communities in Cricova and Goianul Noi stone mines was assessed. The rodent species were the most numerous and spread in the ecosystems of the studied area. 14 species are listed in the Red Book of the Republic of Moldova.
\end{abstract}

\section{Introduction}

The Ichel river is an affluent of Nistru river of the Republic of Moldova. The studied area presents a mosaic landscape, where the remaining natural ecosystems (woods, meadows, steppe sectors, slopes with rocky sites, gorges) alternate with the anthropized ones: shelter belts, agrocoenoses, localities, stone mines, roads. This natural complex is intensely subjected to the action of anthropogenic factors, such as grazing, limestone extraction, wastewater discharge, garbage storage etc. The building of dams and use of river waters for irrigation and aquaculture purposes disturbed the natural course of Ichel river and has affected the natural components of te area. Nevertheless, the terrestrial vertebrate fauna of the area Cricova-Goian from lower Ichel basin is rather rich and at initial fauna inventory there were indicated 97 species of terrestrial vertebrates [2] and up to 138 species in subsequent studies [3, 6]. Data on some bat species in the study area are presented in several studies $[4,5,7,8]$. The aim of the study is to complete the data on diversity and some ecological peculiarities of mammal species the area Cricova-Goian of Ichel river basin.

\section{Materials and methods}

The studies were performed in 2017- 2021 in various types of ecosystems from the area Cricova-Goian of Ichel river basin. The ecosistems were represented by small woods, forest belts, rocky habitats, riverine and paludous biotopes, agrocoenoses and rural localities (fig. 1). The mammal species were recorded by direct observations, using traps (small mammals), counts on the route, after the traces and trophic activity (carnivorous mammals and artiodactyls), catch with nets and use of ultrasound detector (bats). 

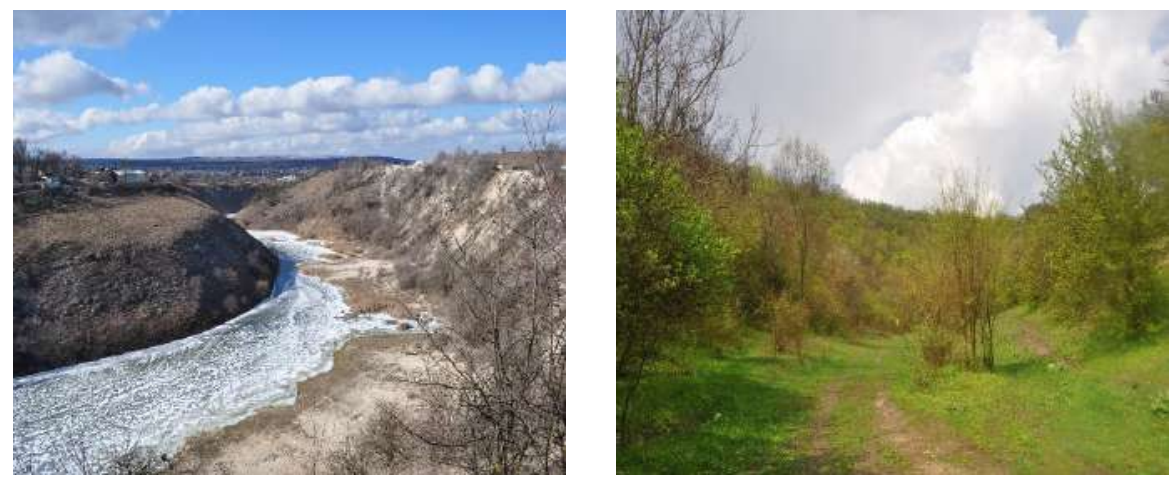

Figure 1. Ichel river and rocky ecosystem of Cricova mines and forest belt near Goianul Nou

In the ecological analysis of mammal communities, the indexes of abundance and frequency were used. Also, the ecological significance was evaluated (W), using the formula $\mathrm{W}=$ $\mathrm{F} \cdot \mathrm{A} / 100$, where $\mathrm{F}$ is frequency of the species and $\mathrm{A}-$ abundance index. The species with the significance lower than $1 \%$ in the studied biocenoses are considered accidental; $1.1-5 \%$ - accessorial; 5.1-10\% - characteristic and $\mathrm{W}>10 \%$ - constant in ecosystem.

\section{Results and discussions}

In the studied ecosystems of Crivova-Goian area 45 species of mammals were registered: one hedgehog species, 5 species of Soricomorpha, 12 bat species, 18 rodent species, one hare species, 6 carnivorous species and 2 artiodactyl species (tab. 1).

Table 1. Diversity and biotopic distribution of mammals species in the studied biotopes from the area Cricova-Goian of Ichel river

\begin{tabular}{|c|c|c|c|c|c|c|c|}
\hline \multirow[b]{2}{*}{ No } & \multirow[b]{2}{*}{ Species } & \multicolumn{5}{|c|}{ Ecosystems } & \multirow[b]{2}{*}{ Locali-ties } \\
\hline & & Forest & Pasture & Rocky sites & Wet & Agroce-noses & \\
\hline & Erinaceomorpha & & & & & & \\
\hline 1 & Erinaceus roumanicus & + & + & + & + & + & + \\
\hline 2 & Soricomorpha & & & & & & \\
\hline 3 & Talpa europaea & + & + & + & + & + & + \\
\hline 4 & Sorex araneus & + & - & - & + & - & - \\
\hline 5 & Sorex minutus & + & - & - & + & - & - \\
\hline 6 & Crocidura leucodon & + & + & - & + & - & - \\
\hline \multirow[t]{2}{*}{7} & Crocidura suaveolens & + & + & - & + & + & + \\
\hline & Chiroptera & & & & & & \\
\hline 8 & Rhinolophus hipposideros & + & - & + & - & - & - \\
\hline 9 & Myotis myotis & - & - & + & - & - & - \\
\hline 10 & Myotis blythii & - & - & + & - & - & - \\
\hline 11 & Myotis bechsteini & - & - & + & - & - & - \\
\hline 12 & Myotis daubentoni & + & - & + & + & - & + \\
\hline
\end{tabular}




\begin{tabular}{|c|c|c|c|c|c|c|c|}
\hline 13 & Myotis dasycneme & + & - & + & + & - & - \\
\hline 14 & Myotis mystacinus & + & - & + & + & - & - \\
\hline 15 & Nyctalus noctula & - & + & - & + & + & + \\
\hline 16 & Pipistrellus pipistrellus & - & - & + & + & + & + \\
\hline 17 & Plecotus auritus & + & - & + & + & - & - \\
\hline 18 & Plecotus austriacus & + & - & + & + & + & + \\
\hline \multirow[t]{2}{*}{19} & Eptesicus serotinus & + & + & + & + & + & + \\
\hline & Rodentia & & & & & & \\
\hline 20 & Sciurus vulgaris & + & - & - & - & - & + \\
\hline 21 & Dryomys nitedula & + & - & - & - & + & - \\
\hline 22 & Muscardinus avellanarius & + & - & - & - & - & - \\
\hline 23 & Nannospalax leucodon & - & + & + & - & + & + \\
\hline 24 & Ondatra zibethicus & - & - & - & + & - & - \\
\hline 25 & Arvicola terrestris & - & - & - & + & - & - \\
\hline 26 & Cricetus cricetus & - & + & - & - & - & - \\
\hline 27 & Rattus norvegicus & - & - & - & - & + & + \\
\hline 28 & Mus musculus & - & - & - & + & + & + \\
\hline 29 & Mus spicilegus & - & + & - & + & + & + \\
\hline 30 & Micromys minutus & - & - & - & + & - & - \\
\hline 31 & Apodemus sylvaticus & + & - & + & + & + & + \\
\hline 32 & Apodemus uralensis & - & + & + & + & + & + \\
\hline 33 & Apodemus flavicollis & + & - & - & - & + & + \\
\hline 34 & Apodemus agrarius & + & + & - & + & + & + \\
\hline 35 & Microtus arvalis & - & + & - & + & - & + \\
\hline 36 & M. rossiaemeridionalis & + & - & - & + & - & + \\
\hline \multirow[t]{2}{*}{37} & Clethrionomys glareolus & + & - & - & - & - & - \\
\hline & Lagomorpha & & & & & & \\
\hline 38 & Lepus europaeus & + & - & - & - & + & - \\
\hline 39 & Carnivora & & & & & & \\
\hline 40 & Felis sylvestris & + & - & - & - & - & - \\
\hline 41 & Lutra lutra & - & - & - & + & - & - \\
\hline 42 & Mustela nivalis & + & - & + & - & + & + \\
\hline 43 & Mustela putorius & + & - & + & - & - & - \\
\hline 44 & Martes foina & + & - & + & - & - & - \\
\hline \multirow[t]{2}{*}{45} & Vulpes vulpes & + & + & + & + & + & + \\
\hline & Artiodactyla & & & & & & \\
\hline 46 & Capreolus capreolus & + & - & - & - & - & - \\
\hline 47 & Sus scrofa & + & - & - & - & + & - \\
\hline
\end{tabular}


The common and eurytopic mammals species, such as the northern white-breasted hedgehog, the mole, the mole-rat, the wood mouse, the fox are frequent and widespread in the studied territory, with a frequency of $47 \%-89 \%$ and a characteristic or constant ecological significance $(\mathrm{W}=8.8-56,4 \%)$.

The shrew species were registered in low number mostly in forest and wet natural biotopes, with accidental or accessorial ecological significance ( $\mathrm{W}=0,6-4,7 \%)$. The white-toothed shrew is a vulnerable species, listed in the Red Book of Moldova (2015).

The bat fauna is represented by 12 species, of which 9 species were registered in Cricova lime stone mines and 10 species in Goianul Nou stone mines (tab. 2,3). The species N. noctula and $P$. pipistrellus were reregistered with the ultrasound detector in the evening period in localities, rocky sites, agrocoenoses. The monitoring of bat hibernation communities in Cricova mines allow to emphasize the multiannual dynamics of bat species (tab. 2).

Table 2. Dynamics of bat community structure (\%) in Cricova mines in the hibernation period

\begin{tabular}{|c|l|c|c|c|c|c|c|c|c|}
\hline No & \multicolumn{1}{|c|}{ Species } & 2013 & 2014 & 2015 & 2016 & 2017 & 2018 & 2019 & 2021 \\
\hline 1 & Rhinolophus hipposideros & - & 12.73 & 7.97 & 5,77 & 10 & 22.54 & 9.09 & 3.33 \\
\hline 2 & Myotis blythii & - & - & - & - & 2 & 1.41 & 3.03 & - \\
\hline 3 & Myotis daubentoni & 51.22 & 41.82 & 65.49 & 71.15 & 50 & 45.07 & 63.64 & 60 \\
\hline 4 & Myotis dasycneme & 29.27 & 5.45 & 12.39 & 13.47 & 22 & 14.08 & 9.09 & 6.67 \\
\hline 5 & Myotis mystacinus & 2.44 & 16.36 & 2.65 & 3.85 & 2 & 1.41 & - & - \\
\hline 6 & Myotis bechsteini & 2.44 & 12.73 & 8.85 & 1.92 & 12 & 9.86 & 12.12 & 20 \\
\hline 7 & Plecotus austriacus & 14.63 & 5.45 & 0.88 & - & 2 & - & - & 6.67 \\
\hline 8 & Plecotus auritus & - & 3.64 & 1.77 & 1.92 & - & 1.41 & 3.03 & 3.33 \\
\hline 9 & Eptesicus serotinus & - & 1.82 & - & 1.92 & - & 4.23 & - & - \\
\hline & Total individuals & 41 & 55 & 113 & 51 & 50 & 71 & 33 & 30 \\
\hline
\end{tabular}

The most numerous during the entire study period was $M$. daubentonii, which represented more than half of the community, followed by $M$. dasycneme with the abundance of $6 \%-30 \%$. Since these species prefer aquatic biotopes, their high proportion in Cricova mines is explained by the proximity of the Ichel river. The third most abundant species was the lesser horseshoe bat, followed by the Bechstein's bat and the whiskered bat. The Plecotus bats constituted 2-6\% of the community, while $M$. blythii and E. serotinus single individuals.

In the Goianul Nou mines the number of individuals is rather low, due to the small surface of the mines, but the bat diversity is high, being registered 10 species. The diversity of bat community is the lowest at the end of hibernation period and the highest in september, when the individuals are intensely feeding and preparing for the hibernation. The most abundant was M. daubentonii, followed by M. myotis and M. bechsteinii (tab. 3).

The mines of Goian have a very low depth and only two species were recorded: $M$. mystacinus and P. austriacus, both protected by low. 
Table 3. Dynamics of bat community structure (\%) in Goianul Nou mines in the study years

\begin{tabular}{|c|l|c|c|c|}
\hline No & \multicolumn{1}{|c|}{ Species } & 04.2016 & 09.2020 & 03.2021 \\
\hline 1 & Rhinolophus hipposideros & 18.18 & - & - \\
\hline 2 & Myotis myotis & - & 2.78 & 29.63 \\
\hline 3 & Myotis blythii & - & - & 7.41 \\
\hline 4 & Myotis daubentoni & 36.36 & 36.11 & 37.03 \\
\hline 5 & Myotis dasycneme & - & 5.56 & - \\
\hline 6 & Myotis mystacinus & 9.09 & - & - \\
\hline 7 & Myotis bechsteini & 36.36 & 11.11 & 18.52 \\
\hline 8 & Plecotus austriacus & - & - & 7.41 \\
\hline 9 & Plecotus auritus & - & 5.56 & - \\
\hline 10 & Eptesicus serotinus & - & 47.22 & - \\
\hline & Total individuals & 11 & 36 & 27 \\
\hline
\end{tabular}

All species identified in Cricova and Goianul Nou mines, except E. serotinus, are rare species, listed in the Red Book of the Republic of Moldova [1] with different rarity criteria. The presence of critically endangered species $M$. myotis and M. bechsteinii is of particular interest and emphasize the importance of these sites in bat diversity conservation in central area of the republic.

The rodent species were the most numerous and spread in the ecosystems of the studied area. The arboreal rodents - the dormouse species and the squirrel were recorded in the forest habitats and at forest edge, especially in forested canyons of the area. The semiaquatic species Arvicola terrestris and Ondatra zibethicus were registered only near Ichel river. A nest of $M i$ cromys minutus was found in the reed thickets on the river bank. The small rodent fauna was represented by 9 species of genera Mus, Apodemus, Microtus, Clethrionomys with characteristic and constant ecological significance $(\mathrm{W}=4.2-53.7 \%)$. At forest edge the dominant species were $A$. syvaticus and A. flavicollis with more that $70 \%$ of small rodent community. In forest belt dominated $A$. uralensis (37.04\%), followed by C. glareolus with $18.52 \%$. In wet ecosystems the highest diversity was registered (8 species), dominant being A. sylvaticus (33.33\%) and $A$. agrarius (31.37\%) and in various types of agrocoenoses dominant was $M$. spicilegus with about $40 \%$, followed by $A$. sylvaticus with about $22 \%$ (fig. 2).

The proximity of Ichel river, the abundant and diverse vegetation, the rocky relief with many canyons and a rich fauna of rodents and birds create favorable conditions for the existence and prosperity of several species of carnivorous mammals (tab. 1). M. nivalis was the rarest species, being observed twice on the rocky slopes near the river meadow [3]. The wild cat (F. silvestris) and the otter (L. lutra) are rare species, listed in the Red Book of Moldova as vulnerable species [1], and were observed several times in forest and riverine habitats of the area.

Two species of artiodactyl mammals (C. capreolus, S. scrofa) were recorded in the area. Both species populate forest ecosystems, but were sporadically observed at forest edge, in for- 


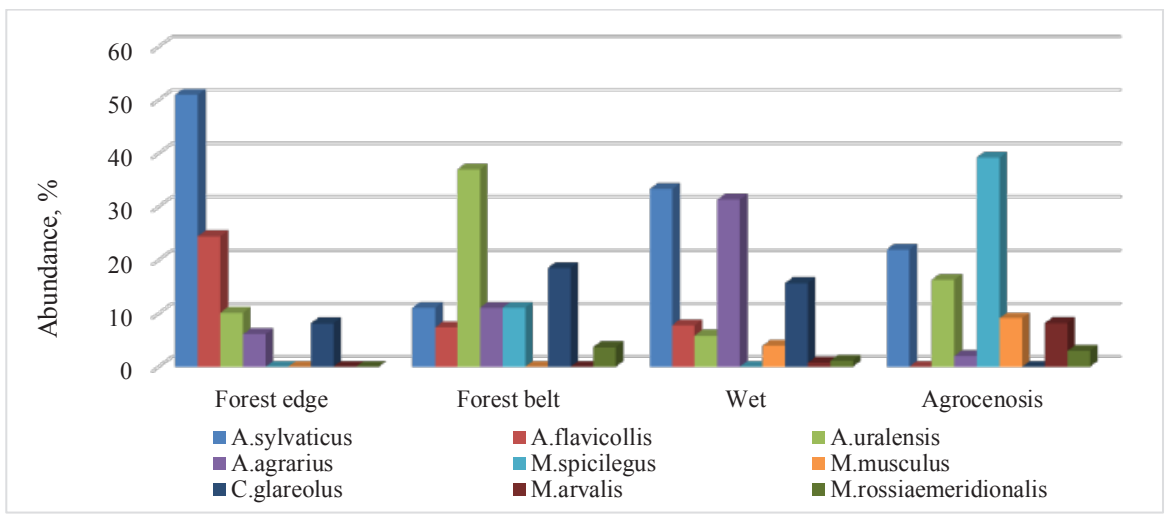

Figure 2. Structure of small rodent communities in various ecosystems of Cricova-Goian area

est shelter belts and in adjacent agricultural ecosystems.

In the localities of the studied area, eight mammal species were registered: E. roumanicus,

$C$. suaveolens, $N$. noctula, P. pipistrellus, E. serotinus, M. musculus, $R$. norvegicus, $V$. vulpes.

The area Cricova-Goianul Nou of Ichel river with a high variety of ecosystems - forest, wet and rocky habitats provide favorable conditions for a high number of mammal species, of which 14 are listed in the Red Book of the Republic of Moldova, despite of strong anthropic disturbances.

The studies were performed within the State Program project 20.80009.7007.02.

\section{Bibliography}

1. Cartea Roşie a Republicii Moldova. Ediţia a III-a. Chişinău, Î.E.P. Știința, 2015, p. 234-265.

2. Cîrlig T., Cîrlig V. Contribuţii la studiul stării faunei vertebratelor ariei naturale Cricova-Goian. Materialele Conferinţei ştiinţifice consacrate aniversării de 85 de ani a UST „Problemele actuale ale ştiinţelor exacte şi ale naturii”, 2015, p. 91-99, Chişinău.

3. Cîrlig V., Cîrlig T., Coadă V., Chiriac E., Nedbaliuc B., Țigănaș A., Pânzaru P., Bejenaru Gh. Contibuţii la studierea faunei şi florei din cadrul ariei naturale a bazinului cursului inferior al râului Ichel. Chişinău, 2017, 163 p.

4. Dibolscaia N. Species diversity and location of bats (Mammalia: Chiroptera) in Cricova stone quarries. 2016. Materials of IX-th International Conference of Zoologists, p. 49-50, Chişinău.

5. Nistreanu V., Andreev S., Larion A., Postolachi V., Caldari V. Data on bat hibernation (Mammalia, Chiroptera) in abandoned stone quarries near Cricova town. DROBETA, Ştiinţele Naturii, XXIV/2014, p. 155-160.

6. Nistreanu V., Cârlig T., Larion A., Turcan V., Burlacu V., Postolachi V. Diversity and status of terrestrial vertebrate fauna in lower course of Ichel river bazin, Republic of Moldova. DROBETA, Ştiinţele Naturii, XXVI, 2016, 115-124.

7. Дорошенко А.В. Места обитания и численность летучих мышей Молдавиию Экология птиц и млекопитающих Молдавии. Кишинев: Штиинца, 1975, с. 82-96.

8. Нистряну В. Б., Калдари В. В., Дибольская Н.М., Ларион А. Ф. Многолетняя динамика зимующих сообществ летучих мышей (Mammalia: Chiroptera) в штольнях поселка Крикова, муниципия Кишинэу, Республика Молдова. Материалы докладов VI Всероссийской заочной научно-практической конференции „Биоразнообразие и рациональное использование природных ресурсов” Махачкала, 2018, с. 137-141. 